McNeill, L.C., Shillington, D.J., Carter, G.D.O., and the Expedition 381 Participants

Proceedings of the International Ocean Discovery Program Volume 381

publications.iodp.org

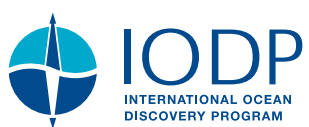

Check for updates

Contents

https://doi.org/10.14379/iodp.proc.381.103.2019

1 Introduction

\section{Expedition 381 facies associations ${ }^{1}$}

L.C. McNeill, D.J. Shillington, G.D.O. Carter, J.D. Everest, E. Le Ber, R.E.Ll. Collier, A. Cvetkoska, G. De Gelder, P. Diz, M.-L. Doan, M. Ford, R.L. Gawthorpe, M. Geraga, J. Gillespie, R. Hemelsdaël, E. Herrero-Bervera, M. Ismaiel, L. Janikian, K. Kouli, S. Li, M.L. Machlus, M. Maffione, C. Mahoney, G. Michas, C. Miller, C.W. Nixon, S.A. Oflaz, A.P. Omale, K. Panagiotopoulos, S. Pechlivanidou, M.P. Phillips, S. Sauer, J. Seguin, S. Sergiou, and N.V. Zakharova ${ }^{2}$

Keywords: International Ocean Discovery Program, IODP, D/V Fugro Synergy, mission-specific platform, Expedition 381, Site M0078, Site M0079, Site M0080, Corinth rift, Gulf of Corinth, Alkyonides Gulf, Eastern Mediterranean Sea, Aegean Sea, continental rifting, extension, active rift, normal fault, earthquake, horst, fault growth, rift development, synrift stratigraphy, drainage evolution, surface processes, basin paleoenvironment, glacio-eustatic cycles, sea level, semi-isolated basin, marine basin, lacustrine, sediment flux, Quaternary, Pliocene, Miocene, carbon cycling, nutrient preservation, marine isotope stage
2 Facies Association 1

2 Facies Association 2

2 Facies Association 3

3 Facies Association 4

4 Facies Association 5

5 Facies Association 6

5 Facies Association 7

5 Facies Association 8

5 Facies Association 9

6 Facies Association 10

7 Facies Association 11

7 Facies Association 12

8 Facies Association 13

9 Facies Association 14

9 Facies Association 15

9 Facies Association 16

10 Facies Association 17

11 Sand and homogeneous mud couplets

\section{Introduction}

In this chapter, we describe the main facies associations that were observed in cores from Expedition 381 and used to describe lithostratigraphic units and subunits at Sites M0078-M0080.

Seventeen facies associations are used to describe the sediment and sedimentary rocks across Sites M0078-M0080. These facies associations are defined based on physical and biogenic features in the sediment, including bedding and lamination style, color, body and trace fossils, and the nature and percentage of sand:

- Facies Association 1 (FA1): homogeneous mud.

- Facies Association 2 (FA2): greenish gray mud with dark gray to black mud to sand beds and laminations.

- Facies Association 3 (FA3): light gray to white laminations alternating with mud and silt beds.

- Facies Association 4 (FA4): laminated greenish gray to gray mud with mud beds.

- Facies Association 5 (FA5): greenish gray mud with homogeneous centimeter-thick gray mud beds.

- Facies Association 6 (FA6): green bedded partly bioturbated mud, silt, and sand.

- Facies Association 7 (FA7): clast-supported sandy conglomerates and pebbly reddish brown sand with silt.
- Facies Association 8 (FA8): reddish brown to brownish gray mud and/or silt, including mottled textures and rootlets.

- Facies Association 9 (FA9): green-gray, often pebbly sandstone/siltstone.

- Facies Association 10 (FA10): interbedded mud/silt and decimeter-thick sand beds.

- Facies Association 11 (FA11): interbedded mud/silt and centimeter-thick sand beds.

- Facies Association 12 (FA12): light gray to buff homogeneous to weakly stratified bioturbated mud.

- Facies Association 13 (FA13): contorted bedding and mud-supported sand and conglomerates.

- Facies Association 14 (FA14): greenish gray pebbly silt and clastsupported fining-upward conglomerates.

- Facies Association 15 (FA15): greenish to buff bioclastic laminated siltstone to bedded fine sandstone, including bioturbation, ostracods, and rootlets.

- Facies Association 16 (FA16): greenish to buff bedded and bioturbated bioclastic sandstone to mudstone.

- Facies Association 17 (FA17): greenish laminated to faintly bedded/homogeneous fossiliferous mudstone.

Sites M0078 and M0079 are characterized by eight mud-dominated facies associations and distinctive sand and homogeneous

\footnotetext{
${ }^{1}$ McNeill, L.C., Shillington, D.J., Carter, G.D.O., Everest, J.D., Le Ber, E., Collier, R.E.Ll., Cvetkoska, A., De Gelder, G., Diz, P., Doan, M.-L., Ford, M., Gawthorpe, R.L., Geraga, M., Gillespie, J., Hemelsdaël, R., Herrero-Bervera, E., Ismaiel, M., Janikian, L., Kouli, K., Li, S., Machlus, M.L., Maffione, M., Mahoney, C., Michas, G., Miller, C., Nixon, C.W., Oflaz, S.A., Omale, A.P., Panagiotopoulos, K., Pechlivanidou, S., Phillips, M.P., Sauer, S., Seguin, J., Sergiou, S., Zakharova, N.V., 2019. Expedition 381 facies associations. In McNeill, L.C., Shillington, D.J., Carter, G.D.O., and the Expedition 381 Participants, Corinth Active Rift Development. Proceedings of the International Ocean Discovery Program, 381: College Station, TX (International Ocean Discovery Program). https://doi.org/10.14379/iodp.proc.381.103.2019

2 Expedition 381 Participants' affiliations.

MS 381-103: Published 28 February 2019

This work is distributed under the Creative Commons Attribution 4.0 International (CC BY 4.0) license. (cc)BY
} 
mud couplets (each couplet is composed of a sand bed below a homogeneous mud bed). These facies associations are FA1, FA2, FA3, FA4, FA5, FA6, FA11, and FA12. In addition, the sand and homogeneous mud couplets combine aspects of the FA1 and FA11 characteristics and occur in most of the facies associations. Site M0080 has the most diverse assemblage of facies associations of all the Expedition 381 sites. In addition to the mud-dominated facies associations and the sand and homogeneous mud couplets that occur at Sites M0078 and M0079, additional facies associations that reflect a wider range of depositional environments and sedimentary processes occur at Site M0080.

\section{Facies Association 1}

\section{Homogeneous mud}

FA1 is dominated by mainly greenish gray, predominantly homogeneous mud that ranges in thickness from a few decimeters to several meters (Figure F1). FA1 is generally overlain and underlain by laminated deposits of FA3 and FA4. The greenish gray (GLEY $16 / 10 Y$ to $5 / 5 \mathrm{GY}$ ) color is characteristic, although the upper $20 \mathrm{~m}$ of each hole is often more olive gray (5Y 6/2 to 4/2). Stratification is uncommon and restricted to sparse indistinct laminations and beds that are distinguished by darker color tones compared to the background sediment. Silty and poor to moderately sorted very fine sand beds are extremely rare, with sand generally $<0.5 \%$ but locally as much as $15 \%$. Bioclasts include shell fragments and individual specimens of gastropods and bivalves. Bioturbation intensity $(\mathrm{BI})$ is high $(\mathrm{BI}>4)$ and often complete $(\mathrm{BI}=6)$, with common burrow-mottled intervals that contain few discernible ichnotaxa. Where discrete traces can be seen, Thalassinoides, Planolites, $\mathrm{Pa}$ laeophycus, and Chondrites were commonly identified. Dark flecks of pyritized organic matter occur scattered in the mud.

\section{Facies Association 2}

Greenish gray mud with dark gray to black mud to sand beds and laminations

FA2 is characterized by interbedded centimeter-thick homogeneous greenish gray mud beds and laminations, together with dark gray to black silt and very fine sand laminations and centimeterthick beds (Figure F2). It forms intervals that range from $0.5 \mathrm{~m}$ to several meters in thickness and is commonly associated with FA4.

Mud beds and laminations in FA2 range from light greenish gray to greenish gray (GLEY $15 / 10 \mathrm{Y}$ to $6 / 10 \mathrm{Y}$ and $6 / 5 \mathrm{GY}$ ), with darker beds ranging from gray to black (GLEY $16 / \mathrm{N}$ to $2.5 / \mathrm{N}$ ). The darker beds appear organic rich relative to the surrounding facies and are often pyritic. Coarser beds usually have sharp bases and tops, but sharp-based, fining-upward beds with gradational tops were also observed. Planar and cross-lamination can occur in the coarser beds, which can also contain rare shell debris. Overall, the percentage of sand in FA2 is $<10 \%$. Charcoal and wood fragments are often found in the darker beds. As a whole, FA2 is unbioturbated; where bioturbation is present, it is generally restricted to the top of the homogeneous mud beds, and at these horizons it is only slight to moderate $(\mathrm{BI}=1-3)$.
Figure F1. FA1 (homogeneous mud) consists of greenish gray homogeneous mud with diffuse bedding and scattered shell fragments, Hole M0078A Subunit 1-3. Top of core image is at $97.00 \mathrm{mbsf}$.

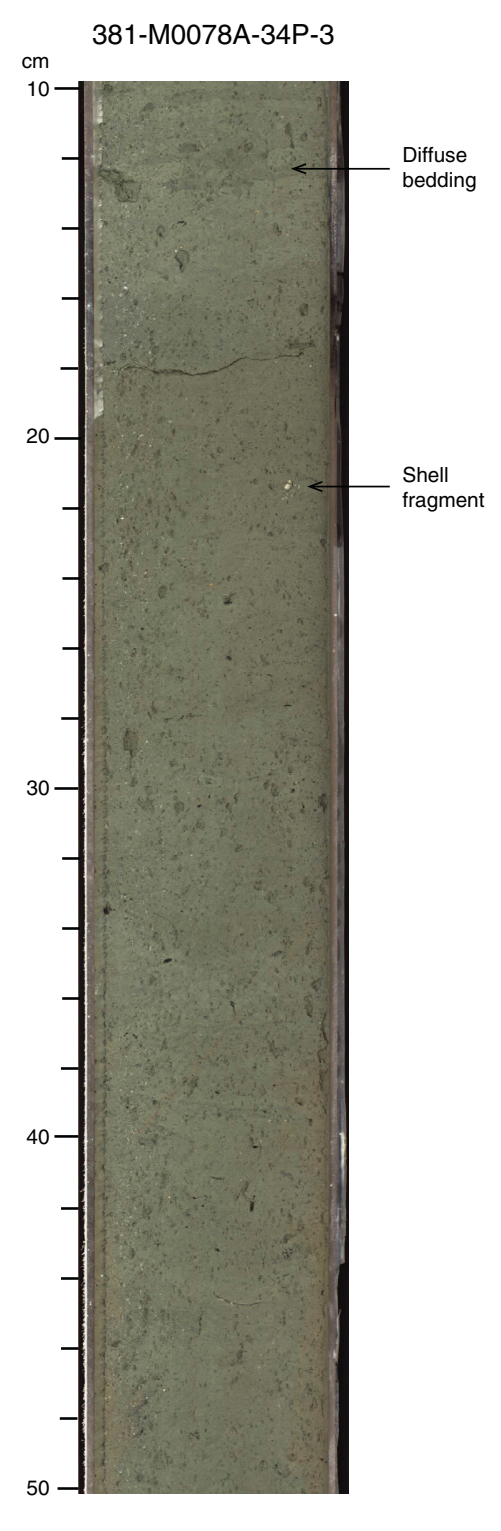

\section{Facies Association 3}

Light gray to white laminations alternating with mud and silt beds

FA3 is characterized by light greenish gray (GLEY $16 / 10 Y$ ) to white/light gray (GLEY $18 / \mathrm{N}$ to $7 / \mathrm{N}$ ) laminations alternating with darker gray to greenish gray laminations at submillimeter scale (Figure F3). Beds composed of these laminations are typically as thick as several decimeters and occur together with centimeter-thick homogeneous mud beds that typically form $<10 \%$ of the facies association. FA3 intervals range from several centimeters to several 
Figure F2. FA2 (greenish gray mud with dark gray to black mud to sand beds and laminations) showing millimeter- to centimeter-thick homogeneous mud beds, laminated mud beds, and organic-rich laminations, Hole M0078A Subunit 1-14. Top of core image is at 338.10 mbsf.

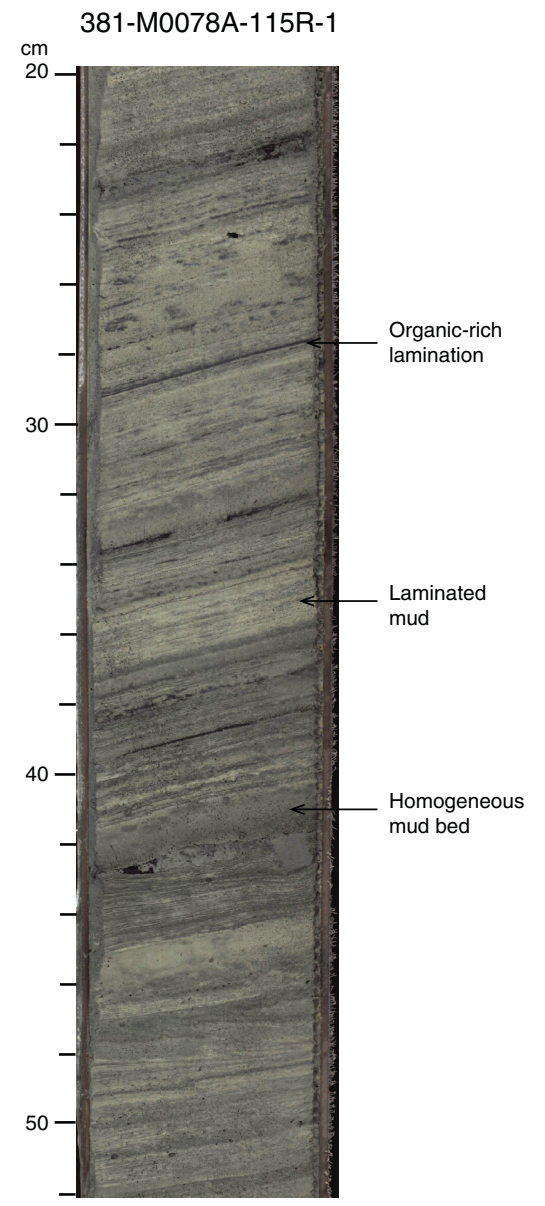

meters in thickness but are generally $<5 \mathrm{~m}$ and regularly lie below FA4 laminated sediment and above FA1 homogeneous sediment.

The beds that comprise the light-colored laminations are composed of either calcite or aragonite. Aragonite-dominated laminations consist of well-sorted, silt-sized, elongated aragonite needles together with diatoms and a small amount $(<10 \%)$ of detrital grains (e.g., well-rounded quartz grains and micas). Calcite-dominated laminations comprise well-sorted, subrounded, fine silt- to claysized grains of calcite, together with diatoms, quartz grains, and organic/pyritized grains.

Other facies in FA3 comprise silty to very fine sand beds $(<1.5$ $\mathrm{cm}$ thick) that often have sharp bases and tops; however, the overall proportion of sand is $<1 \%$. Bioturbation is sparse, is in low abundance where present, and is mainly low-diversity ichnofabric dominated by Planolites or Chondrites.

\section{Facies Association 4}

Laminated greenish gray to gray mud with mud beds

The characteristic FA4 features are laminated greenish gray mud interbedded with $<10 \mathrm{~cm}$ thick homogeneous mud beds (Fig-
Figure F3. FA3 (light gray to white laminations alternating with mud and silt beds) showing thinly laminated mud beds (gray to light gray and beige laminations) and minor millimeter- to centimeter-thick gray homogeneous mud beds, Hole M0078A Subunit 1-3. Top of core image is at 103.85 mbsf.

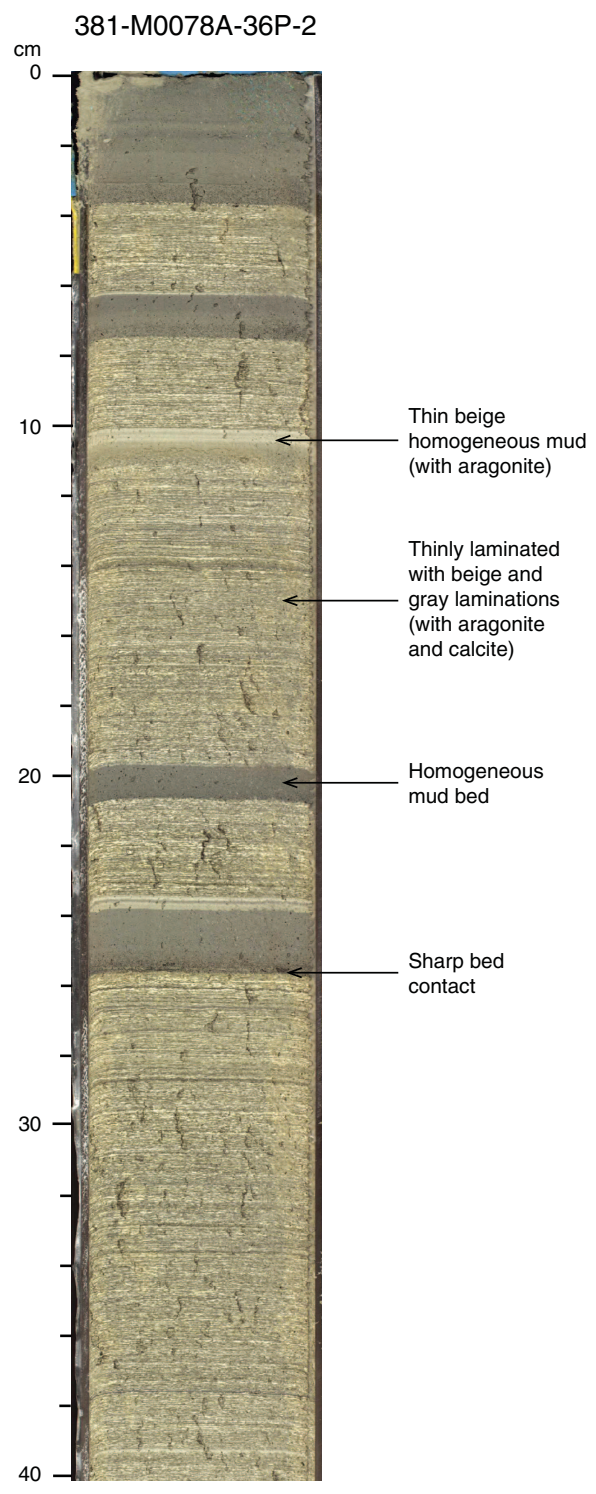

ure F4). The mud ranges from greenish gray to light gray (typically GLEY $15 / 10 Y, 6 / 10 Y$, and 6/N). Other minor facies that occur in FA4 are thin silt and very fine sand beds, typically $0.5-4 \mathrm{~cm}$ thick, that often have sharp bases and display normal grading. The sand beds may contain planar lamination, cross-lamination, and shell debris and comprise $<10 \%$ of the facies association. Rare black (organic-rich?) laminations may also be present.

The homogeneous mud occasionally contains some black undetermined fragments, organic-rich beds (millimeter to centimeter scale), and rare small horizontal and/or oblique burrows likely to be Planolites and larger (5-10 $\mathrm{mm}$ in diameter) oval burrows. Overall, bioturbation intensity is low $(\mathrm{BI}=0-2)$. Shell fragments may be scattered in variable proportions through the mud beds and were sometimes observed in the rare thin sandy beds. 
Figure F4. FA4 (laminated greenish gray to gray mud with mud beds) mainly consists of laminated mud with centimeter-thick homogeneous mud beds and common organic-rich laminations, Hole M0078A Subunit 1-2. Thin silt and very fine sand beds are also present. Top of core image is at $85.99 \mathrm{mbsf}$.

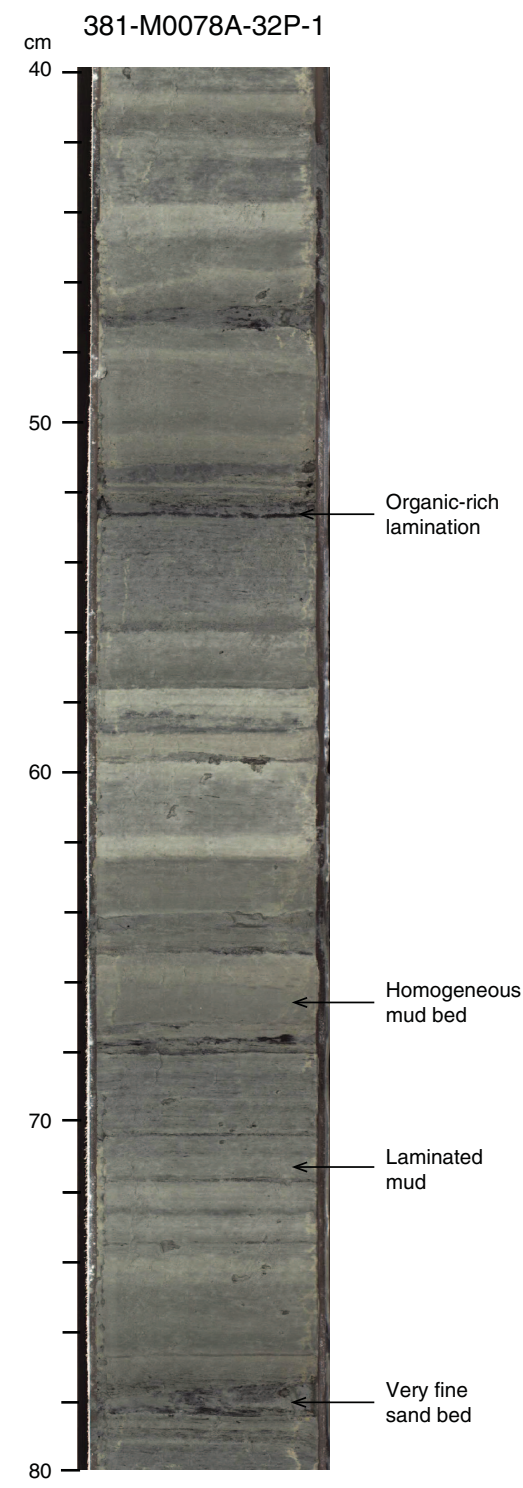

\section{Facies Association 5}

Greenish gray mud with homogeneous centimeter-thick gray mud beds

FA5 is characterized by centimeter-thick bedded greenish gray mud that may be interbedded with homogeneous mud, laminated mud, and thin silt and sand beds (Figure F5). FA5 is generally overlain or underlain by FA1 or FA4.

The most common facies, typically comprising $50 \%-100 \%$ of FA5, is $1-5 \mathrm{~cm}$ thick, faintly laminated mud beds that are typically light greenish gray (GLEY $17 / 10 Y$ ) to gray (GLEY $15 / \mathrm{N}$ ). Homogeneous mud beds typically comprise $10 \%-40 \%$ of the facies association and are typically $0.5-20 \mathrm{~cm}$ in thickness. Beds vary considerably from dark gray (GLEY $14 / 2$ ) through greenish gray
Figure F5. FA5 (greenish gray mud with homogeneous centimeter-thick gray mud beds) showing interbedded centimeter-thick mud beds with some millimeter-thick fine sand beds, Hole M0078A Subunit 1-4. In addition to the typical gray mud beds of FA5, some reddish gray mud beds are also visible. Top of core image is at $139.54 \mathrm{mbsf}$.

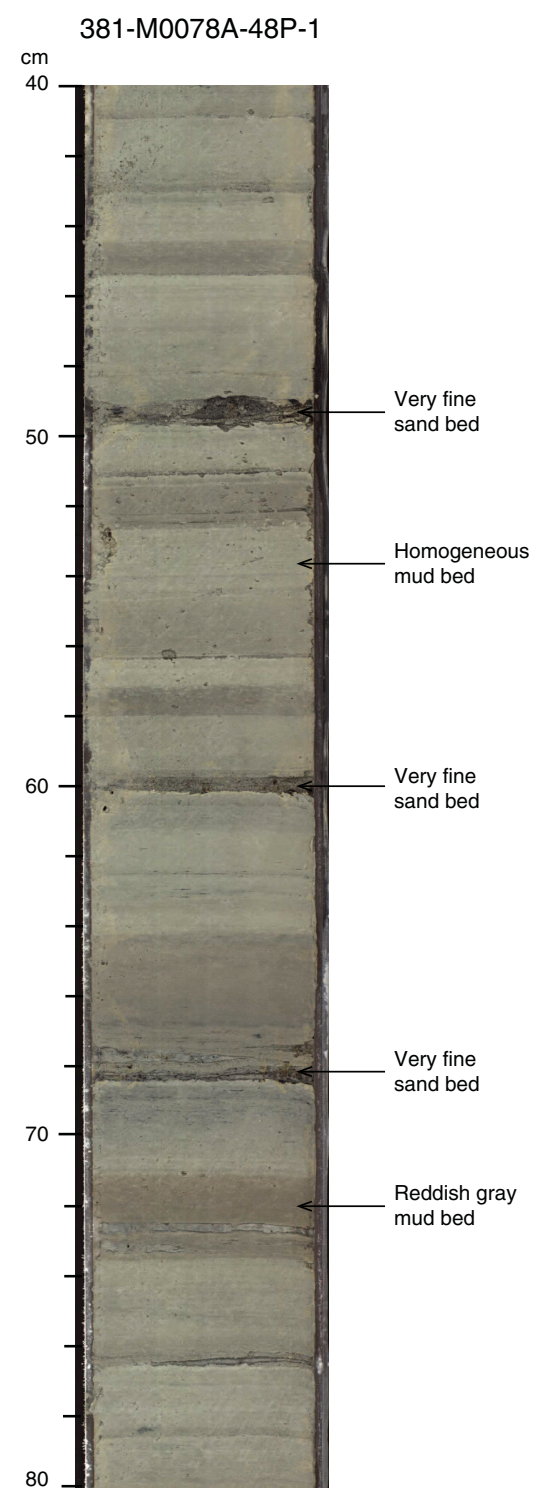

(GLEY 15/10Y) to a range of reddish brown colors (reddish or pinkish gray [5YR 6/2 to 7.5YR 5/2]). The top few millimeters of these beds are sometimes moderately bioturbated by small Planolites and possibly Chondrites. Thicker $(>10 \mathrm{~cm})$ beds may be moderately to abundantly bioturbated throughout.

Thin $(>1 \mathrm{~cm})$ silt beds typically comprise only a small percentage of the total thickness of any given section. These beds may be massive or laminated and usually have sharp bases, with both sharp and graded tops common. Very fine and fine sand beds are also found occasionally and are typically $<1 \mathrm{~cm}$ thick (maximum $=2-3$ $\mathrm{cm}$ ). Sand and silt beds are usually dark gray (GLEY $14 / \mathrm{N}$ ) or otherwise a darker shade of the surrounding mud color. Rare pyrite, organic material (plant debris or charcoal), and shell fragments found scattered in FA5 are most abundant in sand rather than in mud. 


\section{Facies Association 6}

Green bedded partly bioturbated mud, silt, and sand

FA6 is characterized by moderately to extensively bioturbated mainly greenish gray mud (GLEY $16 / 10$ to $6 / 5 \mathrm{GY}$ ) but also includes more olive and darker greenish mud (5Y 6/2 to 7/2) (Figure F6). The main difference between FA6 and FA1, which FA6 is most commonly associated with, is the visibility of remnant bedding and/or silt and very fine sand laminations; the remnant bedding often presents as faint boundaries between mud of a slightly different color across which a variation in bioturbation type or intensity occurs. Beds are typically centimeters thick but can be up to several tens of centimeters thick, and they commonly have sharp bases and sharp to gradational tops. Beds with sandy bases commonly fine upward from very fine to fine sand, with coarser grain sizes occasionally present, and may contain parallel and cross-lamination. Bioturbation intensity generally varies from 2 to 6 . Discrete ichnofabrics occur in some core sections in FA6, including simple millimeter-scale horizontal burrows (e.g., Chondrites or Planolites), Teichichnus, and Palaeophycus. Mottling also occurs in areas of higher bioturbation intensity. Scattered shell fragments, foraminifers, and pyrite are also found in FA6.

\section{Facies Association 7}

Clast-supported sandy conglomerates and pebbly reddish brown sand with silt

FA7 encompasses a range of clast-supported, poorly to moderately sorted pebble conglomerates, typically with medium to coarse pebbles but occasionally including scattered cobbles (Figure F7). Conglomerate beds vary from a few centimeters to about $40 \mathrm{~cm}$ in thickness, with bed boundaries poorly defined and sedimentary structures generally absent. Crude parallel bedding was occasionally observed. Both normal and reverse grading occurs. The typical reddish brown colors vary from 10YR 4/3 to 7.5YR 6/4. Clast compositions vary but include prerift lithologies such as limestone, mafic/ultramafic rocks, and red chert and a range of intraclasts. Clasts of reworked previously cemented sandy conglomerate can also be seen.

The more poorly sorted pebble conglomerates typically include medium to coarse sand as a clast-supporting, finer grained component. These sandy conglomerates can vary toward pebbly sand. The conglomerates are commonly interbedded with FA8 gray to brown mud or silt on a decimeter scale. The clast-supported sandy conglomerates can also include varying amounts of calcrete from weakly developed concretions to more intensively developed zones of carbonate cementation several centimeters to a few tens of centimeters thick.

\section{Facies Association 8}

Reddish brown to brownish gray mud and/or silt, including mottled textures and rootlets

FA8 reddish brown to brownish gray (7.5YR 5/3 to $5 Y$ 5/1) mud and silt are generally mottled due to bioturbation, with some discrete feeding traces and simple vertical and subhorizontal burrows evident (Figure F8). Bedding is commonly diffuse and rarely well defined as a result. Infrequent centimeter-thick very fine or fine sand beds may occur in the gray to reddish brown mud and silt. Scattered coarse sand grains and granules may also occur.
Figure F6. FA6 (green bedded partly bioturbated mud, silt, and sand) showing bioturbated and faintly bedded greenish gray mud, Hole M0079A Subunit 1-7. Top of core image is at 403.50 mbsf.

381-M0079A-95R-3

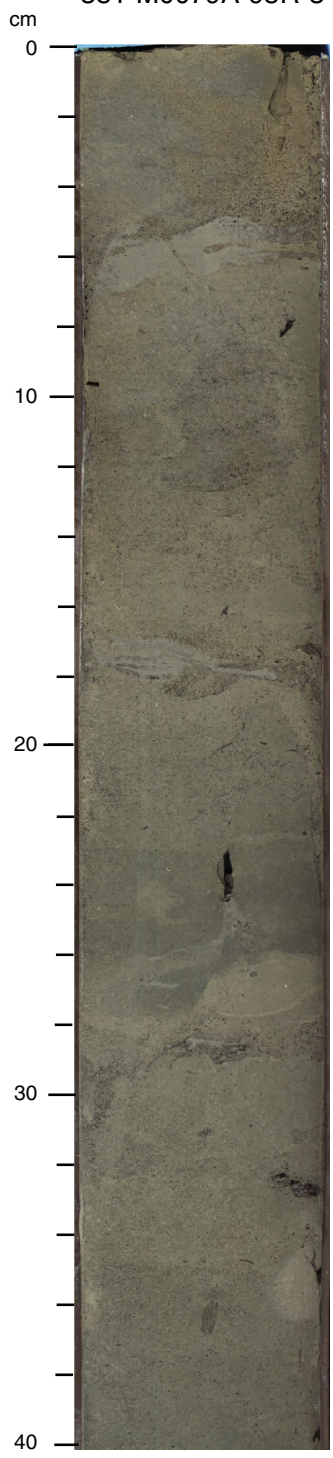

The reddish brown silt and mud may include prismatic textures (vertical cracks), rhizoliths, and irregular subvertical hollow tubes with reduction halos. These features are typically $2-8 \mathrm{~cm}$ long and are interpreted as indicative of soil formation and rootlets. A variety of rubbly, pseudobrecciated, and mottled textures can also be seen. Variably developed calcrete nodules and patches were observed in the mud and silt, generally $1-3 \mathrm{~cm}$ in diameter (Figure F8). These nodules and patches sometimes appear to exploit and be best developed in silt- or sand-filled burrows.

\section{Facies Association 9}

\section{Green-gray, often pebbly sandstone/siltstone}

FA9 is an intermediate facies association between FA8 and FA7 (Figure F9). Bedding is at best poorly defined, if observable at all. Where it can be observed, the pebbly sandstone and siltstone are predominantly gray green (GLEY $17 / 10 Y$ ) rather than the reddish 
Figure F7. FA7 (clast-supported sandy conglomerates and pebbly reddish brown sand with silt) showing clast-supported conglomerate dominated by mafic/ultramafic clasts with minor micritic limestone and red chert clasts, Hole M0080A Subunit 3-1. Conglomerates have no clear bedding or internal structures. Top of core image is at 330.06 mbsf.

\section{1-M0080A-93R-1}

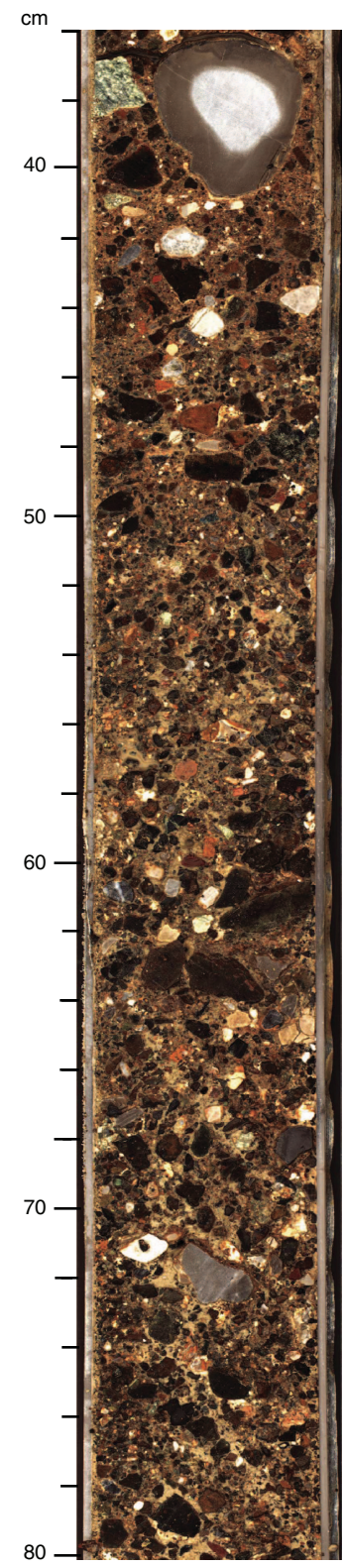

brown seen in FA7 and FA8. Pseudobreccia textures and calcrete nodules were not seen. Scattered granules and small pebbles of red chert, mafic/ultramafic lithologies, and rare limestone are also present. Bioturbation is sparse.

\section{Facies Association 10}

Interbedded mud/silt and decimeter-thick sand beds

FA10 features sand beds that are several tens of centimeters thick that either fine upward into or are interbedded with laminated to massive greenish gray mud (Figure F10). The sand may be very
Figure F8. FA8 (reddish brown to brownish gray mud and/or silt, including mottled textures and rootlets) showing homogeneous muddy silt with discrete calcrete nodules, Hole M0080A Subunit 3-2. Top of core image is at $416.20 \mathrm{mbsf}$.

$$
\text { 381-M0080A-116R-1 }
$$

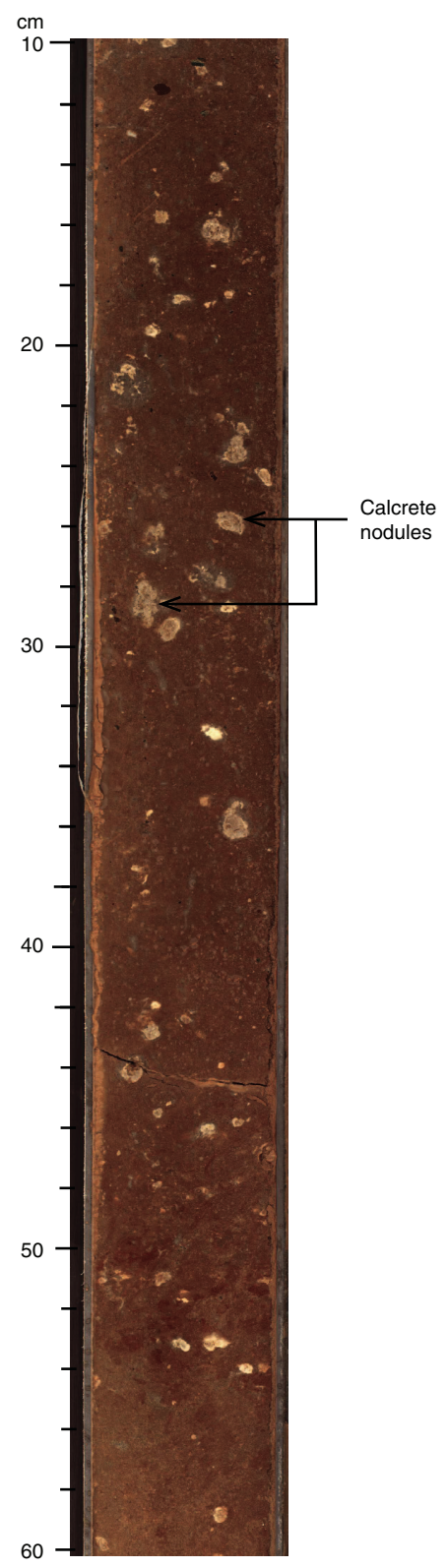

coarse, coarse, or medium grained at the base and fines upward gradationally through silt into mud. Scattered granules may occur in the coarser bases of the sand beds. The FA10 sand tends to be relatively dark gray (typically GLEY $14 / \mathrm{N}$ ) and is devoid of visible bioturbation. FA10 most commonly occurs with mud-dominated FA4, FA2, and FA5 and with interbedded mud/silt and centimeter-thick sand beds (FA11).

The basal parts of the sand may be massive. Where present, sedimentary structures include parallel and ripple cross-lamination. Beds are typically sharp-based and/or infill centimeter-amplitude topography between clasts on the top of underlying FA13 intraclast conglomerates. The basal sand fines upward into interbedded very fine sand and silt or just silt, and these elements commonly are pla- 
Figure F9. FA9 (green-gray, often pebbly sandstone/siltstone) showing sandstone with scattered rounded mafic/ultramafic and rare limestone pebbles, Hole M0080A Subunit 4-3. The represented section is affected by tectonic faulting and drilling-induced fractures. Top of core image is at $529.50 \mathrm{mbsf}$.

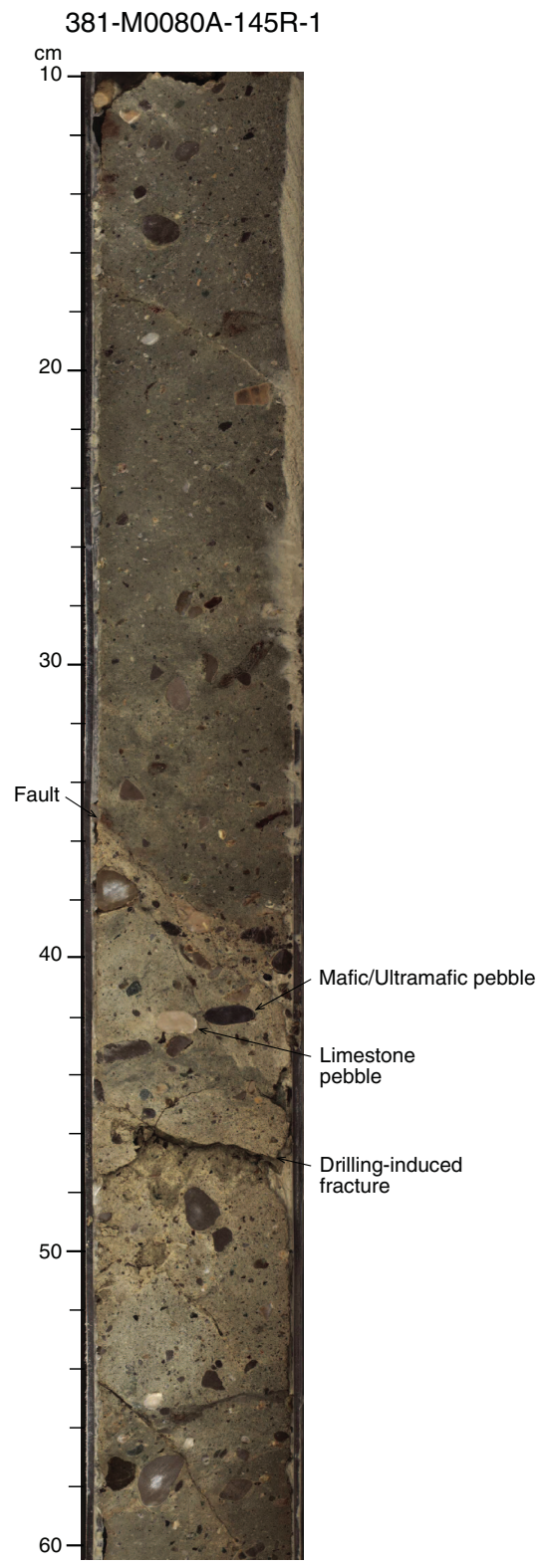

nar laminated. Above the silt, the fining-upward trend continues into mud that is greenish gray or gray (GLEY $16 / 10 Y$ to $5 Y$ 6/1). For the most part, the mud lacks bioturbation and bioclasts. The mud is homogeneous to weakly bedded, with any faint bedding being picked out by minor color changes or slight grain size variations.

\section{Facies Association 11}

Interbedded mud/silt and centimeter-thick sand beds

FA11 is characterized by greenish gray (GLEY 1 6/10Y) mud interbedded with gray (GLEY $14 / \mathrm{N}$ to $5 \mathrm{Y} 5-6 / 1$ ) and rarely yellowish (5Y 6/4) centimeter-thick sand beds that range from very fine to very coarse sand (Figure F11). Sedimentary structures developed in these sand beds mainly comprise parallel and (planar) cross-bed-
Figure F10. FA10 (interbedded mud/silt and decimeter-thick sand beds) with a sharp base above FA5. FA10 consists of an $18 \mathrm{~cm}$ thick sand bed (dark gray) fining upward through silt to a weakly bedded mud, Hole M0079A Subunit 1-15. Top of core image is at $624.55 \mathrm{mbsf}$.

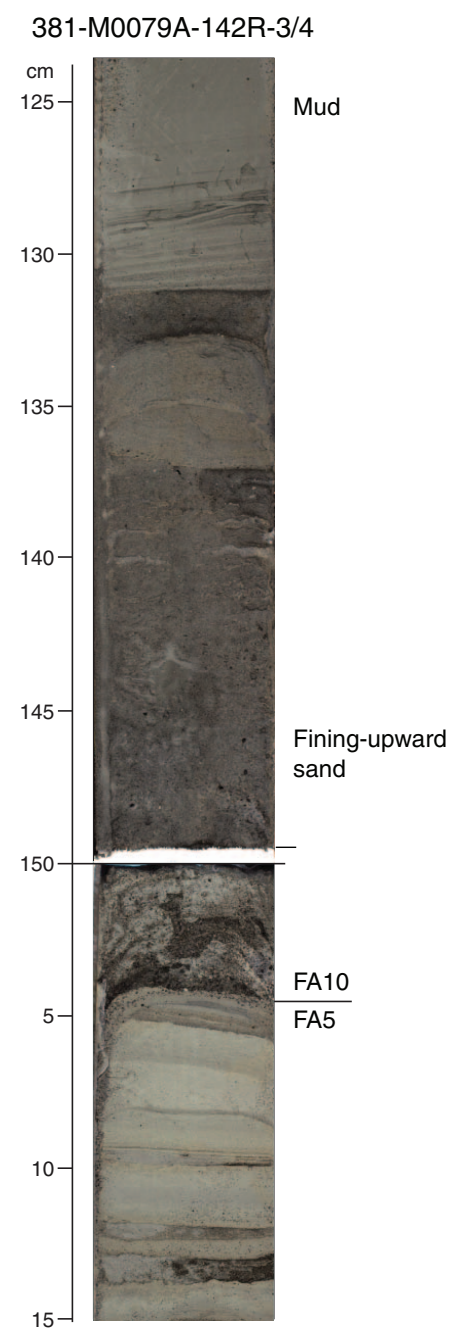

ding. The sand beds can be bioturbated and are usually sharp based but may either have a sharp top or fine upward into silt and mud. The background mud beds are commonly poorly stratified or homogeneous with locally moderate to high bioturbation intensity (BI $=2-5$ ), typically localized at the top of the beds or at or beneath the base of the sand. Sand beds typically comprise $>7.5 \%$ of the total unit thickness. FA11 most commonly occurs with the other muddominated facies associations (FA4, FA2, and FA5) and with decimeter-thick sand (FA10).

\section{Facies Association 12}

Light gray to buff homogeneous to weakly stratified bioturbated mud

FA12 consists predominantly of mud that varies from light gray/gray (GLEY $17 / \mathrm{N}$ or $6 / \mathrm{N}$ ) to light greenish gray/greenish gray (GLEY 1 7/10Y or 6/10Y) with rare pinkish or light reddish/buff gray sections (2.5YR 7/2 or 5 YR 7/2) (Figure F12). FA12 consists almost entirely of highly bioturbated homogeneous to weakly laminated mud. Pyrite and organic smears/flecks are rare to common 
Figure F11. Typical section of FA11 (interbedded mud/silt and centimeterthick sand beds) showing centimeter-thick sand beds with lamination and some bioturbation in a succession of homogeneous, weakly bedded, or laminated mud with bioturbation, Hole M0078A Subunit 1-2. Top of core image is at 30.82 mbsf.

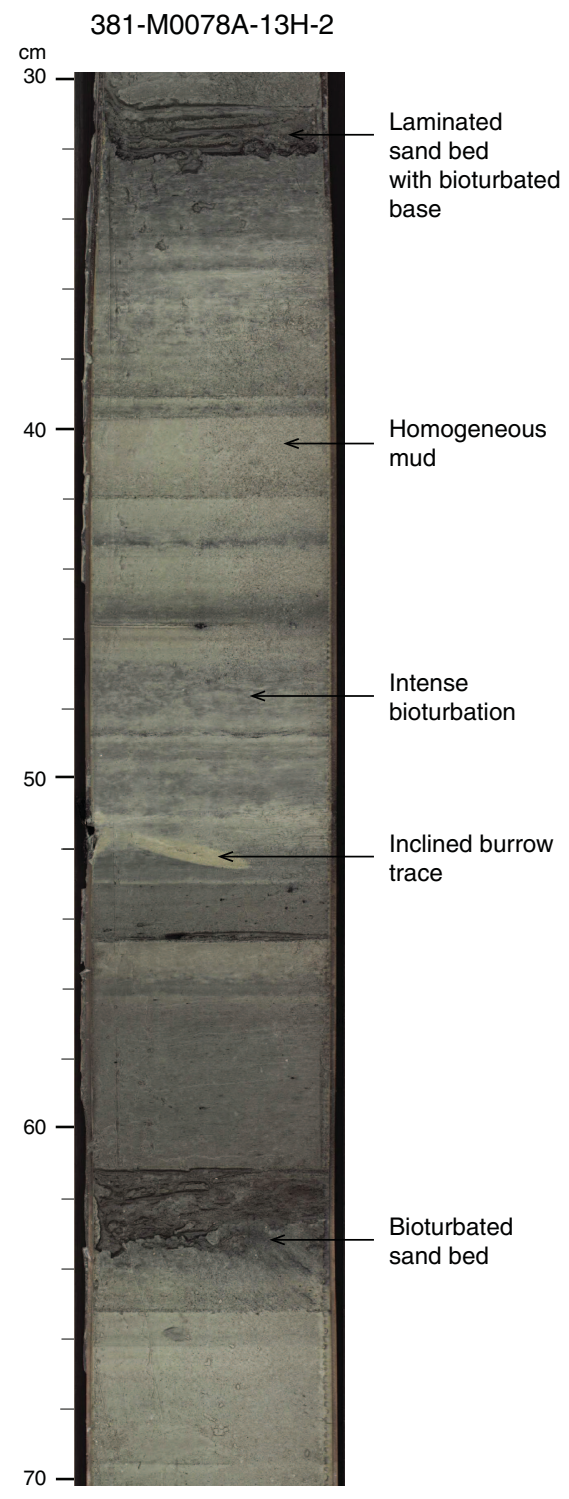

and are found throughout FA12. Silt and sand are generally absent. Two subfacies associations are identified based on the color, degree of preserved lamination and bedding, and degree of bioturbation.

Most FA12 intervals are highly to completely bioturbated $(\mathrm{BI}=$ $5-6)$, and a minority are moderately bioturbated $(\mathrm{BI}=3-4)$. The trace fossils, where observed, are mainly characterized by small (millimeter-sized), subhorizontal, simple burrows, including Planolites and possibly Chondrites. The more bioturbated (BI = 5-6) subfacies association contains few laminations and is light gray or light greenish gray. Because of the high degree of bioturbation, it is difficult to identify specific traces, and the sediment has a mottled texture, although possible Teichichnus burrows can be recognized locally. The less bioturbated ( $\mathrm{BI}=3-4)$ subfacies association preserves dark (millimeter-scale) laminations and beds with $<2-15 \mathrm{~cm}$ spacing. Overall it is typically darker gray (GLEY $15 / \mathrm{N}$ or $6 / \mathrm{N}$ ) than the highly bioturbated subfacies association and is less abundant.
Figure F12. Typical section of FA12 (light gray to buff homogeneous to weakly stratified bioturbated mud) showing pale gray heavily bioturbated homogeneous mud, Hole M0078A Unit 2. Faint laminations and abundant organic flecks can be seen throughout the section; a pyritized burrow is also shown. Top of core image is at 549.55 mbsf.

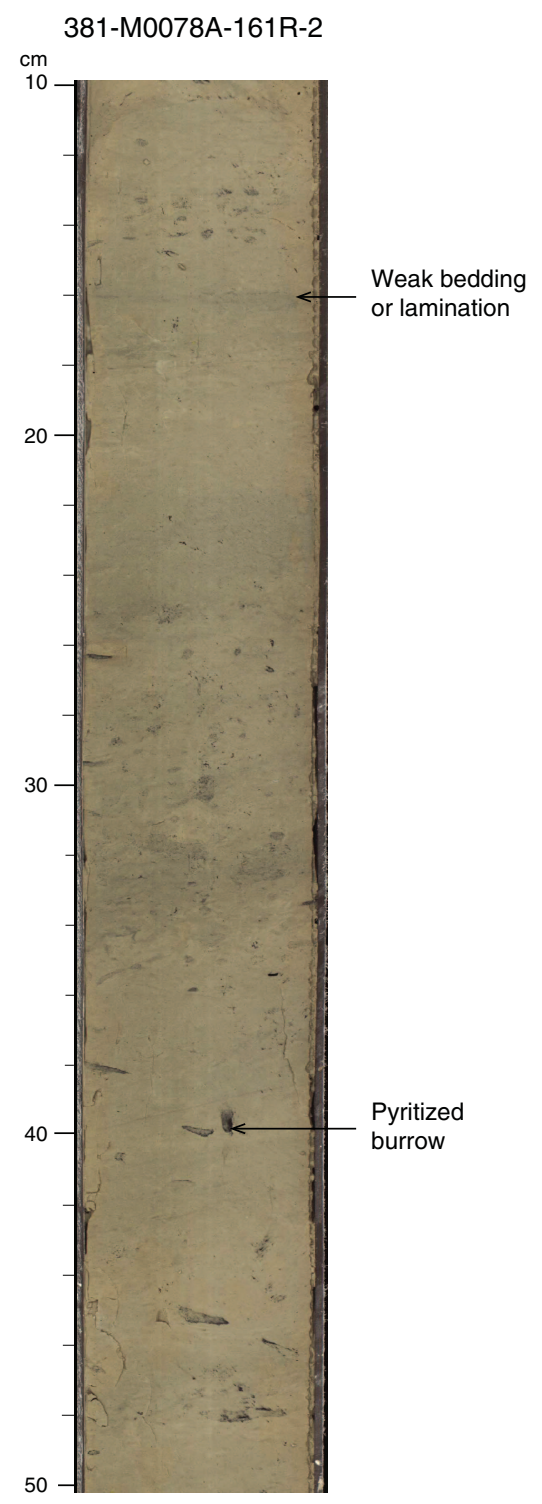

Facies Association 13

Contorted bedding and mud-supported sand and conglomerates

FA13 involves two sedimentary deposit types that may occur separately or together: (1) mud-supported conglomerates and (2) contorted bedding (Figure F13). These deposits range from $\sim 10$ $\mathrm{cm}$ to $12 \mathrm{~m}$ in thickness, typically have a sharp lower boundary, and are commonly overlain by a sand and homogeneous mud couplet or FA10.

The mud-supported conglomerates are characterized by numerous clasts ranging in size from coarse sand to cobble that are supported and separated by a muddy matrix (e.g., Figure F13A). The clasts are poorly sorted and rounded. The larger clasts are predominantly mud intraclasts (laminated or homogeneous) with 
Figure F13. Examples of the two sedimentary deposit types identified as FA13 (contorted bedding and mud-supported sand and conglomerates) and corresponding grain size log (left to right: $\mathrm{m}=$ mud, $\mathrm{si}=$ silt, $\mathrm{vf}=$ very fine sand, $\mathrm{f}=$ fine sand, $\mathrm{m}=$ medium sand, $\mathrm{c}=$ coarse sand, $\mathrm{v} c=$ very coarse sand, $\mathrm{g}=$ granules, $\mathrm{p}=$ pebbles, $\mathrm{c}=$ cobbles). A. Deposit of mud-supported clasts overlain by a sand and mud couplet (only partly shown in figure), Hole M0079A Subunit 1-9. Top of core image is at $458.6 \mathrm{mbsf}$. B. Deposit of contorted bedding overlain by a sand and mud couplet (only partly shown in figure), Hole M0079A Subunit 1-14. Top of core image is at $564.10 \mathrm{mbsf}$.
A

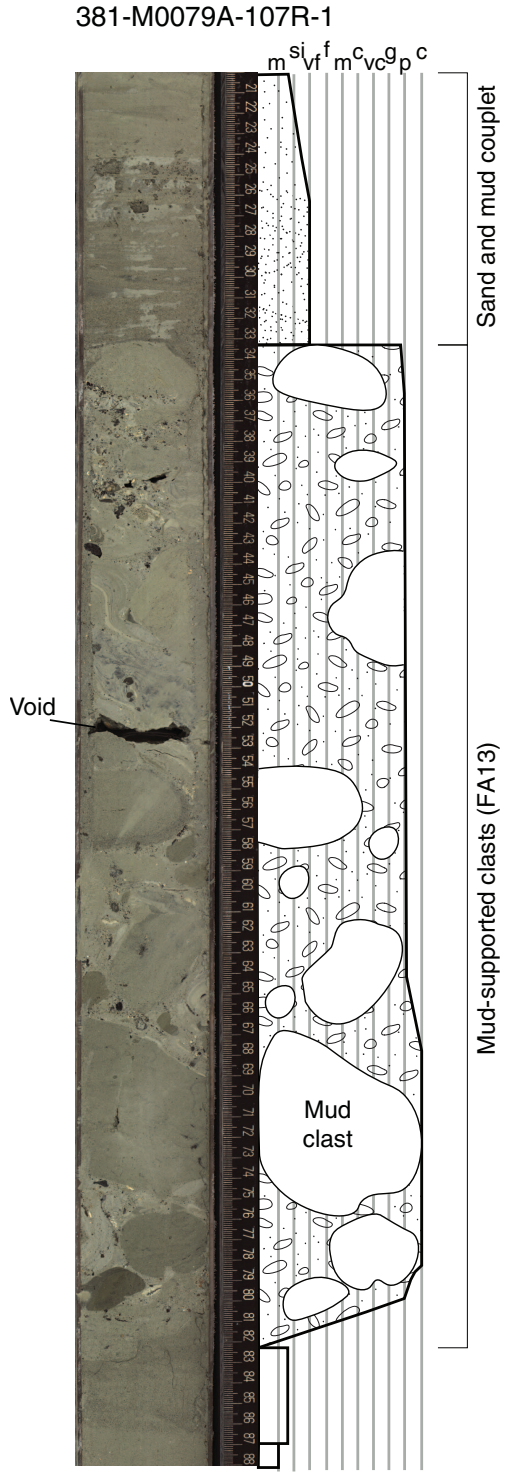

B 381-M0079A-129R-1

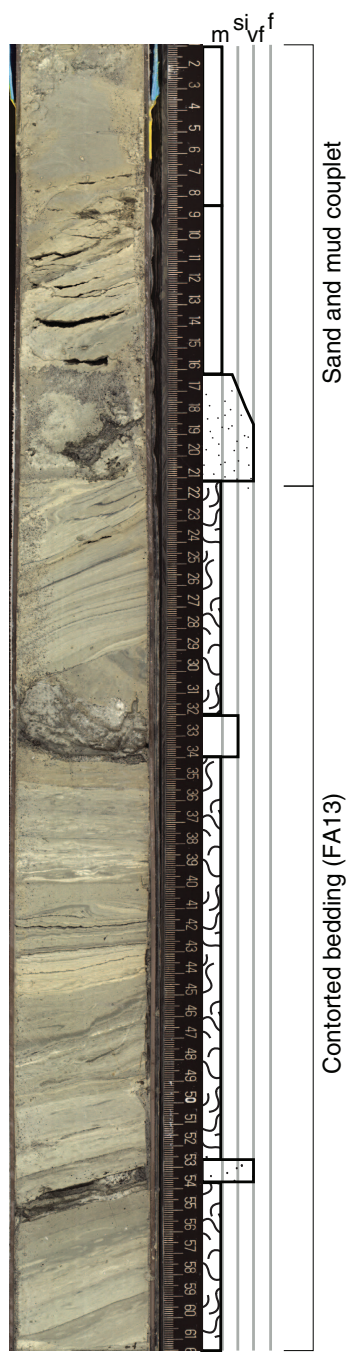

ent beds (on the scale of the core) are often interlayered with folded intervals. Although these more coherent beds can appear intact, they can be overturned as indicated by way-up criteria such as graded bedding, erosional surfaces, and cross-lamination. The base of contorted bedding packages often show evidence of shearing and/or discrete shear/slip surfaces.

\section{Facies Association 14}

\author{
Greenish gray pebbly silt and clast-supported fining-upward \\ conglomerates
}

FA14 encompasses three main facies: (1) pale greenish gray silt (GLEY 1 5/10Y to 6/10Y), which includes scattered pebbles and granules; (2) pebbly, laminated medium sand often developed at the top of fining-upward conglomerate packages; and (3) normally graded, clast-supported granule and pebble conglomerates and sandy pebble conglomerates (Figure F14). The granule and pebble conglomerates are very poorly to poorly sorted with angular and subangular grains and clasts. The conglomerates are sharp based with some crude bedding and include some imbricated pebbles. Bed thicknesses range from 4 to $45 \mathrm{~cm}$ in the pebbly sand and pebble conglomerates and from 12 to $42 \mathrm{~cm}$ in the greenish gray silt with scattered pebbles.

\section{Facies Association 15}

Greenish to buff bioclastic laminated siltstone to bedded fine sandstone, including bioturbation, ostracods, and rootlets

FA15 includes bioclastic siltstone that is laminated to weakly laminated on a subcentimeter scale or bedded on a centimeter to decimeter scale (Figure F15). FA15 may also include coarsening-upward structureless very fine to medium sandstone that is commonly overlain by FA14 sandy conglomerates. Levels of bioturbation in both the siltstone and sandstone vary from sparse to moderate, with simple horizontal burrow forms, Planolites, vertical burrows filled with coarser grains as long as $10 \mathrm{~cm}$, subvertical and patchy feeding traces, and pervasive burrow mottling. Bioclastic (thin shell) fragments may be scattered or form bioclastic-rich beds a few centimeters thick and coquinas of concentrated open framework shell debris. Ostracods and scaphopods are frequently scattered through buff silt laminations and beds but also form centimeter-thick very fine sand-grade packstone to grainstone with planar laminations. Root traces may also occur in the laminated and bedded buff siltstone, commonly associated with beds with the highest abundance of ostracod-rich laminations. The laminated to bedded siltstone varies from dark greenish gray to buff (GLEY 1 6/5GY, GLEY $17 / 10 Y$ to $7 / 5 \mathrm{GY}$, and 10YR 7/3).

\section{Facies Association 16}

smaller clasts (pebble to coarse sand) of mud, sand, and limestone. The mud matrix ranges from light gray to greenish gray (GLEY $17 / 10 Y$ to $5 / 5 \mathrm{GY}$ ). These beds can be topped by a very coarse lithic sand- to granule-grade conglomerate and be overlain by a sand and mud couplet (or FA10).

Contorted bedding packages comprise folded and sheared laminated mud of one or more of the following facies associations: FA1, FA2, FA3, FA4, FA5, FA6, FA10, FA11, or FA12 (e.g., Figure F13B). A range of fold sizes and styles can occur, including millimeter- to centimeter-scale isoclinal folds, centimeter- to decimeter-scale open folds, and complex refolded folds. Unfolded and more coher-

\section{Greenish to buff bedded and bioturbated bioclastic sandstone to mudstone}

FA16 is primarily characterized as calcareous and bioclastic very fine to medium-grade packstone to grainstone (Figure F16). Bedding is variably visible, giving crude planar bedding with beds as thick as several tens of centimeters. Where distinct beds are absent, may be normally graded. Scattered thin shell fragments are common and may include gastropods, bivalves, and ostracods. Rare FA16 has a more homogeneous character than the sandstone. Beds 
Figure F14. FA14 (greenish gray pebbly silt and clast-supported finingupward conglomerates) showing fining-upward, crudely stratified pebble conglomerate with predominantly mafic/ultramafic clasts (dark) and rare limestone clasts (light), Hole M0080A Subunit 2-5. Base of the bed is not present in this core section. Top of core image is at $252.88 \mathrm{mbsf}$.

381-M0080A-67R-2

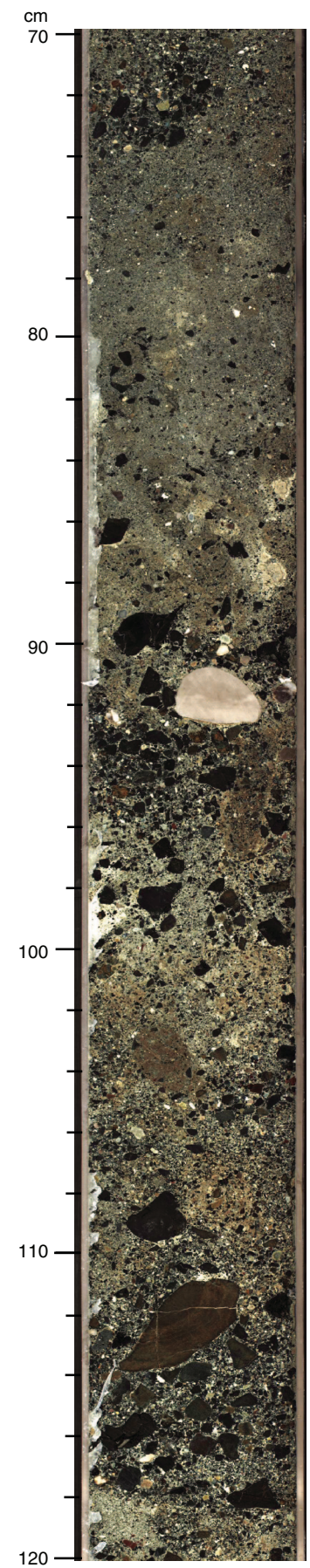

lithic granules are also scattered throughout the sandstone. Colors range from greenish to buff ( $5 \mathrm{Y} 5 / 2$ to $10 \mathrm{YR} 6 / 2$ ) to more dark greenish colors (5Y 4/1) when mud is present and when transitioning to FA17.
Figure F15. Typical FA15 (greenish to buff bioclastic laminated siltstone to bedded fine sandstone, including bioturbation, ostracods, and rootlets) showing a buff calcareous siltstone with diffuse planar or slightly undulating laminations, Hole M0080A Subunit 4-1. Top of core image is at 460.90 mbsf.

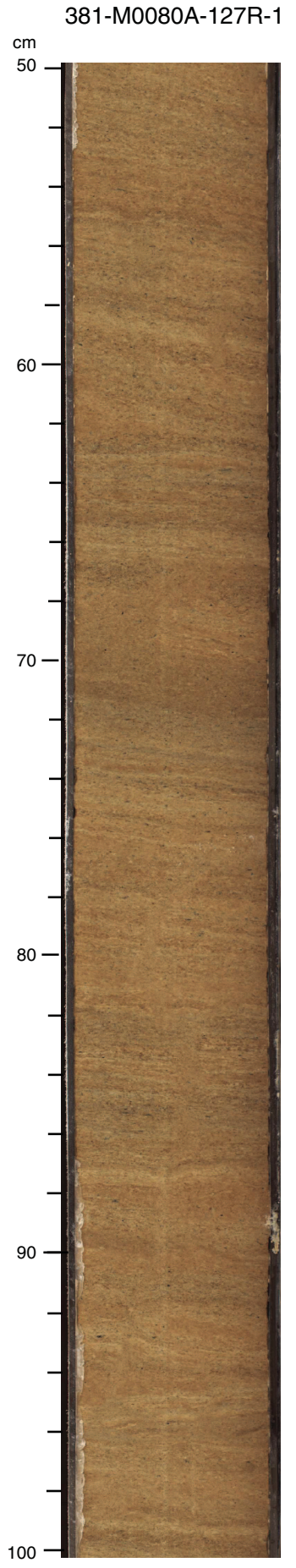

\section{Facies Association 17}

Greenish laminated to faintly bedded/homogeneous fossiliferous mudstone 
Figure F16. Typical FA16 (greenish to buff bedded and bioturbated bioclastic sandstone to mudstone) showing faintly bedded brown grayish very fine sandstone with abundant ostracods and other shell fragments, Hole M0080A Subunit 4-2. Top of core image is at 503.24 mbsf.

381-M0080A-137R-3

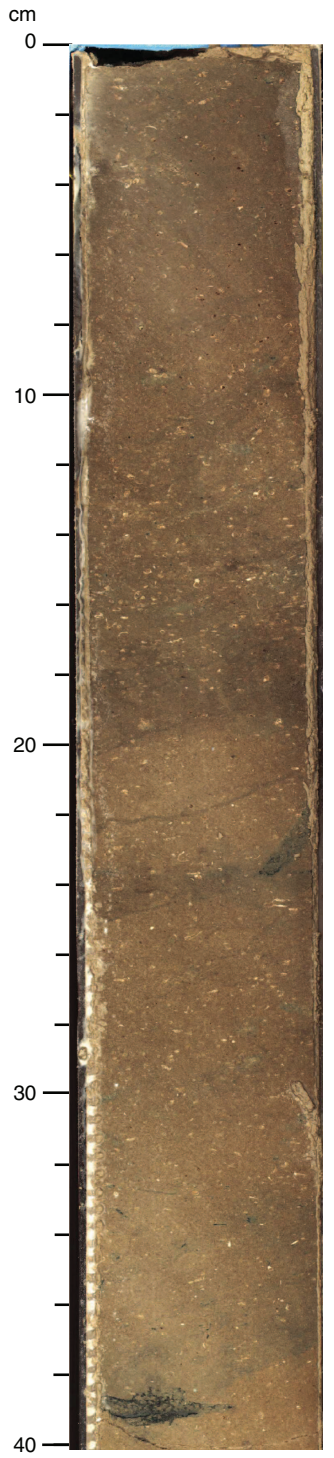

FA17 is characterized by faintly bedded or homogeneous dark greenish or blueish gray mudstone (GLEY $14 / 5 \mathrm{G}$ to 5/10GY) but also includes interbeds of current rippled and laminated to bedded siltstone and sandstone (Figure F17). These multicolored interbeds (overall 2.5Y 6/3) occur when FA17 transitions from FA16 bedded very fine bioclastic sandstone. Mud in FA17 is commonly structureless but also includes faintly bedded siltstone and sandstone beds and occasional fining-upward, poorly sorted, clast-supported granule conglomerate to pebbly sandstone beds as thick as $25 \mathrm{~cm}$. Bioturbation intensity varies from sparse in some of the coarser grained horizons to abundant or complete $(B I=4-6)$ in the dark greenish mudstone. Carbonate cement occupies some silt- or sand-filled burrows or forms centimeter-scale, irregular-shaped patches. Shell fragments occur with rare intact fossils, including gastropods and scaphopods.
Figure F17. FA17 (greenish laminated to faintly bedded/homogeneous fossiliferous mudstone) characterized by homogeneous dark green mudstone with carbonate concretions and scattered shell fragments, Hole M0080A Subunit 4-2. Top of core image is at 524.60 mbsf.

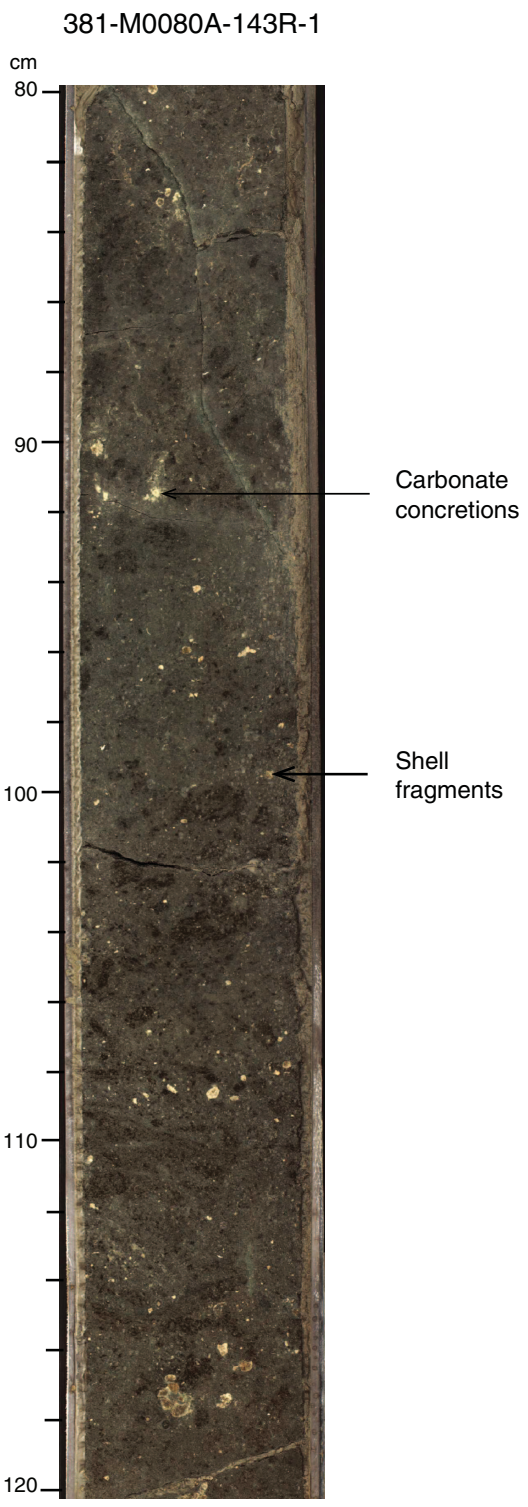

\section{Sand and homogeneous mud couplets}

Coupled sand and homogeneous mud deposits (Figure F18) are found in the majority of the facies associations in Unit 1 and more rarely in Unit 2 and thus are described separately here but are not assigned to a facies association. These deposits comprise a lower sand interval overlain by homogeneous mud and range in thickness from a few centimeters to several meters.

The sand beds typically have a sharp and sometimes erosive contact with underlying facies and are typically between 0.5 and 20 $\mathrm{cm}$ thick. The beds consist of a coarse silt to sandy base (typically very fine sand), sometimes with thin parallel and cross-lamination, as well as scattered shell and organic fragments. The sand comprises one or more fining-upward intervals and is typically overlain by a highly homogeneous mud-dominated bed with a green to gray 
Figure F18. Sand and homogeneous mud couplet interbedded with FA11, Hole M0078A Subunit 1-2. Top of core image is at 22.36 mbsf.

\section{$381-\mathrm{M} 0078 \mathrm{~A}-10 \mathrm{H}-1$}

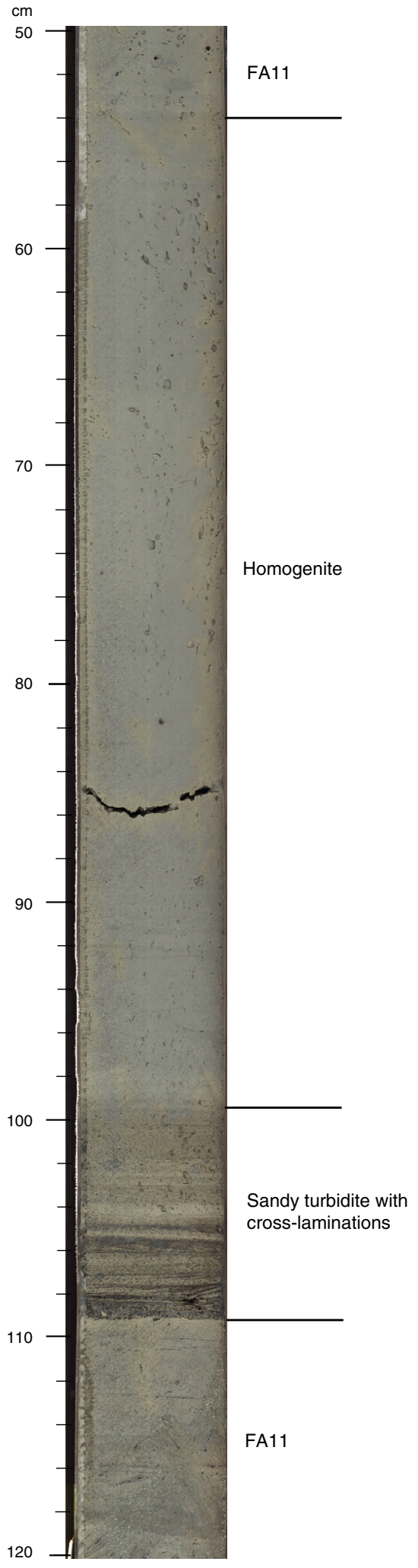

color (GLEY $15 / 10 Y$ to $5 / \mathrm{N}$ ). The mud beds are typically $10-20 \mathrm{~cm}$ thick but have a wide range in thickness from $3 \mathrm{~cm}$ to $3.5 \mathrm{~m}$. The homogeneous mud often contains organic material, sometimes clearly terrestrial derived (e.g., leaves), and pyrite. The transition between sand and homogeneous mud can be sharp or gradual. The top of these deposits is usually sharp and is sometimes bioturbated. 